\title{
ПРОБЛЕМЫ АНТРОПОЛОГИИ
}

УДК 572.9; 572.77; 03.61.21

DOI: $10.17223 / 19988613 / 68 / 20$

\author{
Г.А. Аксянова
}

\section{ПЕРВЫЕ ПОКОЛЕНИЯ РУССКОГО НАСЕЛЕНИЯ В ОМСКОМ ПРИИРТЫШЬЕ ХVII-ХІХ ВВ. ПО ДАННЫМ ОДОНТОЛОГИИ}

\author{
Исследование выполнено за счет гранта РНФ «Русское население Сибири XVII-XIX вв.: этнокультурная адаптачия \\ в археологическом и антропологическом измерении» (проект № 18-18-00487).
}

\begin{abstract}
Статья представляет расширенный вариант доклада, прочитанного на юбилейной XVIII Международной Западносибирской археолого-этнографической конференции «Западная Сибирь в транскультурном пространстве Северной Евразии: итоги и перспективы 50 лет исследований ЗСАЭК», состоявшейся 16-18 декабря 2020 г. на базе Томского государственного университета.
\end{abstract}

\begin{abstract}
Впервые по одонтологической программе изучена морфология зубной системы в четырех краниологических сериях русских первопоселенцев Среднего Прииртышья: Ананьино I, Изюк I, Тара-2013 и Бутырское кладбище в г. Омске. Коллекции черепов датируются XVII-XIX вв., представляют православные сельские и городские популяции. Статистические сравнения групп из азиатской и европейской частей России, сопоставление с сибирскими татарами показали сохранение русскими сибиряками европейских черт в одонтологическом комплексе. Наряду с этим выявлены признаки ограниченного биологического контакта с азиатским коренным населением. Ключевые слова: русские; Сибирь; Новое время; физическая антропология; одонтология.
\end{abstract}

Начало массового продвижения великорусского населения в Сибирь с целью экономического освоения территории, расширения границ Российского государства и закрепления на азиатских территориях относится к началу Нового времени (конец XVI - XVII в.). Массовая миграция привела к серьезным демографическим и социальным последствиям в регионе: быстрому приросту численности нового населения, взаимодействию с коренными сообществами, появлению городов и острогов, установлению новой властной структуры, распространению русской культуры, языка и православия, миссионерской деятельностью Русской православной церкви в среде аборигенного языческого населения. В антропологическом отношении эти процессы приводили к расширению биологического разнообразия постоянно проживающего населения.

Цель настоящего исследования - получить объективную антропологическую характеристику ранних популяций русского населения средней части Западносибирской равнины для решения вопросов его формирования и биологической адаптации в новых условиях проживания. Источником необходимой информации стали фонетические особенности морфологии зубной системы человека, ее постоянной смены в краниологических коллекциях. Материалы представлены суммарными по полу выборками. По расширенной одонтологической программе изучены четыре локальные серии русских первопоселенцев в Среднем Прииртышье: Изюк I, Ананьино I, Тара-2013 и «русская часть» Бутырского кладбища в г. Омске. Коллекции мужских, женских, частично детских черепов были получены за последние десятилетия в ходе археологических работ под руководством Л.В. Татауровой, М.П. Чёрной и М.А. Корусенко на кладбищах поселенческих комплексов трех районов Омской области (Россия). Материалы поступили на хранение в фонды Кабинета антропологии Томского государственного университета и Тюменского научного центра СО РАН. Серии относятся к XVII-XIX вв. и характеризуют сельские и городские популяции православного населения. К сравнению привлечен широкий круг авторских материалов по русскому и коренному населению последних столетий с территории Сибири, включая современные популяции тюркских и уральских народов, кетов, русских Приобья и Красноярска, метисов, а также северных / вологодских русских г. Устюжна. Опубликованные данные представлены краниологическими сериями из православных некрополей нескольких европейских городов Поволжья (Казанский Кремль, Чебоксары и Тверь) [1-2].

Антропологическое изучение православного, в основном великорусского, населения Сибири, включая потомков национально-смешанных браков, одними из первых провели Н.Л. Геккер и И.И. Майнов во время своих работ в Якутии на рубеже XIX-XX вв. [3-5]. C.M. Чугунов в тот же период изучил население Томска XVII-XVIII вв. по собранному на православных кладбищах города краниологическому материалу, который был почти полностью повторно захоронен после антропологического изучения. Это исследование 
в 1970-е гг. продолжил В.А. Дрёмов, а недавно Д.В. Пежемский, И.Г. Широбоков [6-9]. Новые серии русских жителей Томска, Красноярска и Омской области XVII-XIX вв., которые стали объектом одонтологического исследования, ранее получили краниологическую, палеопатологическую и демографическую характеристику [10-15].

С середины 1920-х гг. и до конца двадцатого столетия в азиатской части России обследованы только современные популяции русских старожилов по нескольким методическим программам и в широком территориальном диапазоне - от Горного Алтая, Оби и Енисея до Забайкалья и Камчатки. Обзору этих работ посвящено несколько публикаций [16-18]. Систематический сбор краниологических коллекций из православных некрополей Нового времени расширился в постсоветское время в связи с процессом восстановления исторического прошлого городских и сельских поселений в Сибири, отразивших расширение границ Российского государства и массовое продвижение русского населения за Урал. Антропологами изучено несколько краниологических коллекций из Восточной Сибири, Приамурья по традиционным программам краниометрии, одонтологии. Постепенное накопление материалов параллельно идет и на синхронных объектах в европейской части страны $[1,2,17,19]$. В 1970-е гг. В.Ф. Ващаева обследовала десятки современных русских популяций по всему ареалу исторического формирования этноса на Восточноевропейской равнине [20-21]. Тем самым была создана надежная цифровая основа для сравнения азиатских и европейских групп одного народа.

Программа одонтологического исследования краниологических серий включает несколько десятков маркеров-фенов, в проявлении которых есть собственно генетическое влияние. Она составлена по методическим пособиям, написанным основателем российской одонтологической школы А.А. Зубовым [22-25].
Наряду с описательными характеристиками в нее входит измерительный комплекс размеров коронок больших коренных зубов (моляров).

Изученные в процессе настоящего исследования русские серии Омской области и Красноярска относятся по мировому масштабу к категории микродонтов, что характерно для евразийских популяций. Исключение мезодонтизм - в Томской коллекции, в которой абсолютно преобладают мужские черепа. Проведено графическое сравнение всех групп по двум интегрированным показателям величины коронки моляров: среднему размеру (модулю, m cp.) и форме (индексу, ср. инд.). Для зубов нижней челюсти показано, что все православные выборки ясно различаются с этнически пестрой совокупностью дославянских групп Западной Сибири, в том числе удалены от локальных групп тарских татар - Токсай, Чеплярово и Черталы (рис. 1, табл. 1). Сельские выборки Изюк и Ананьино оказались более однотипными, чем городские. При этом Тара - городская серия более раннего исторического периода - находится в поле графика ближе к массиву уральских и тюркских групп, чем более поздняя серия Бутырского кладбища.

Частота встречаемости разных признаков в комплексе определяет одонтологический тип группы и ее положение на европеоидно-монголоидной шкале евразийского диапазона различий (табл. 2). Во всех изученных сериях Омского Прииртышья преобладает западный (европеоидный) компонент, который максимально выражен в двух сельских выборках (Изюк, Ананьино), а минимально в Таре. Эта, пока еще очень малочисленная, выборка по целому ряду таксономически важных фенов отклоняется к метисным группам. Здесь повышены частоты лопатообразных обоих резцов, коленчатой складки, извилистой формы борозды 1 ра, затеков эмали, шестых бугорков на $\mathrm{M}_{2}$. В первую очередь в составе данной выборки могут быть крещеные аборигены, видимо, татары.



Рис. 1. Положение русских и татарских групп в системе западносибирских этносов по средним относительным показателям размеров трех нижних моляров. Ось $x$ - средний модуль ряда $\mathrm{M}_{1}-\mathrm{M}_{3}$ (мм); ось $y-$ средний индекс ряда $\mathrm{M}_{1}-\mathrm{M}_{3}(\%)$ 
Средний модуль (мм) и средний индекс (\%) коронки моляров в исследованных краниологических сериях Западной Сибири (оба пола суммарно)

\begin{tabular}{|c|c|c|c|c|c|}
\hline Краниологические серии & $\begin{array}{l}\mathrm{mcp} . \\
\mathrm{M}^{1-3}\end{array}$ & $\begin{array}{c}\mathrm{m} \text { cp. } \\
\mathrm{M}_{1-3}\end{array}$ & $\begin{array}{c}\text { ср.инд. } \\
\mathrm{M}^{1-3}\end{array}$ & $\begin{array}{c}\text { ср.инд. } \\
\mathrm{M}_{1-3}\end{array}$ & Местонахождение \\
\hline \multicolumn{6}{|c|}{ Православные группы (русские), XVII-XVIII-XIX вв. } \\
\hline Покровский некрополь & 10,00 & 10,15 & 113,45 & 96,17 & г. Красноярск, XVII-XVIII вв. \\
\hline Ананьино I & 10,00 & 10,21 & 114,45 & 96,35 & Тарский р-н, Омская обл., XVII-XVIII вв. \\
\hline Tapa 2013 & 9,97 & 10,18 & 117,06 & 97,14 & г. Тара, Тарский р-н, Омская обл., XVII-XVIII вв. \\
\hline Изюк I & 9,96 & 10,21 & 112,05 & 96,16 & Большереченский р-н, Омская обл., XVII-XIX вв. \\
\hline Бутырское кладбище «русская часть» & 10,04 & 10,30 & 112,59 & 94,62 & г. Омск, XIX в.; преобладают мужчины \\
\hline Томск суммарно (БАМ + Чугунов) & 10,25 & 10,42 & 111,59 & 93,58 & $\begin{array}{c}\text { г. Томск, Богородице-Алексиевский монастырь, } \\
\text { XVIII-XIX вв.; преобладают мужчины }\end{array}$ \\
\hline $\begin{array}{l}\text { Коллекция } \\
\text { С.М. Чугунова }\end{array}$ & 10,18 & 10,39 & 112,79 & 94,61 & $\begin{array}{c}\text { г. Томск, полицейский участок и разные находки, } \\
\text { XVII-XIX вв.; преобладают мужчины }\end{array}$ \\
\hline \multicolumn{6}{|c|}{ Дославянские автохтоны, XV-XX вв. } \\
\hline Татары тарские, Чеплярово 27 & 9,95 & 10,11 & 111,85 & 98,33 & Большереченский р-н, Омская обл. \\
\hline Татары тарские, Черталы 3 & 9,96 & 9,95 & 109,17 & 97,70 & Муромцевский р-н, Омская обл. \\
\hline Татары тарские, Токсай & 9,59 & 10,17 & 114,30 & 99,10 & То же \\
\hline $\begin{array}{l}\text { Татары сибирские } \\
\text { (9 гр. без Чеплярово и Черталы) }\end{array}$ & 9,88 & 10,11 & 113,07 & 97,73 & Четыре области Западной Сибири \\
\hline Ханты суммарно & 9,94 & 10,21 & 114,44 & 98,50 & Тюменская обл. \\
\hline Манси суммарно & 9,76 & 9,97 & 112,81 & 95,92 & То же \\
\hline Селькупы нарымские суммарно & 9,87 & 10,17 & 114,63 & 98,80 & Томская обл. \\
\hline Кеты суммарно & 10,12 & 10,26 & 113,33 & 98,45 & Красноярский край \\
\hline
\end{tabular}

Таблица 2

Частота одонтологических признаков у русских Омского Прииртышья XVII-XIX вв. (оба пола суммарно)

\begin{tabular}{|c|c|c|c|c|}
\hline Признак & & Омская область & & г. Омск, Бутырское кладбище \\
\hline Памятник и датировка & $\begin{array}{c}\text { Ананьино I } \\
\text { XVII-XVIII вв. }\end{array}$ & $\begin{array}{c}\text { Tара } 2013 \\
\text { XVII-XVIII вв. }\end{array}$ & $\begin{array}{c}\text { Изюк I } \\
\text { XVII-XIX вв. }\end{array}$ & «русская часть», XIX в. \\
\hline Частота и объем выборки & $\%(\mathrm{~N})$ & $\%(\mathrm{~N})$ & $\%(\mathrm{~N})$ & $\%(\mathrm{~N})$ \\
\hline Диастема I ${ }^{1}-\mathrm{I}^{1}$ & $0(21)$ & $0(8)$ & $6,3(74)$ & $3,3(30)$ \\
\hline Краудинг I² (лингвльный сдвиг) & $0(21)$ & $0(9)$ & $0(78)$ & $0(31)$ \\
\hline Редукция I² (баллы $2+3)$ & $0(19)$ & $0(7)$ & $1,3(75)$ & $0(30)$ \\
\hline Гиподонтия I ${ }^{2}$ & $5,3(19)$ & $0(9)$ & $3,8(79)$ & $0(30)$ \\
\hline Редукция hy $\mathrm{M}^{2}$ (баллы 3 и 3+) & $38,7(13)$ & $60(5)$ & $28,4(60)$ & $41,4(29)$ \\
\hline * Лопатообразность резцов I ${ }^{1}$ (баллы $2+3$ ) & $0(6)$ & $25(4)$ & $6,5(31)$ & $4,3(23)$ \\
\hline Лопатообразность резцов I² (баллы $2+3$ ) & $12,5(8)$ & $33,3(6)$ & $18,8(32)$ & $4,2(24)$ \\
\hline * Дистальный гребень тригонида $\mathrm{M}_{1}(\mathrm{dtc})$ & $11,1(9)$ & $0(2)$ & $3,7(27)$ & $22,2(18)$ \\
\hline * Коленчатая складка метаконида $\mathrm{M}_{1}(\mathrm{dw})$ & $11,1(9)$ & $50(2)$ & $8,8(17)$ & $0(7)$ \\
\hline * $\mathrm{M}_{1} 6$ бугорков & $0(14)$ & $0(6)$ & $10(50)$ & $0(26)$ \\
\hline ** $\mathrm{M}_{1} 4$ бугорка & $21,4(14)$ & $33,3(6)$ & $16(50)$ & $7,7(26)$ \\
\hline $\mathrm{M}_{2} 6$ бугорков & $0(15)$ & $16,7(6)$ & $0(63)$ & $3,7(27)$ \\
\hline ** $\mathrm{M}_{2} 4$ бугорка & $80(15)$ & $33,3(6)$ & $96,8(63)$ & $77,8(27)$ \\
\hline ** Бугорок Карабелли на $\mathrm{M}^{1}$ (баллы 2-5) & $6,7(15)$ & $0(6)$ & $27,8(36)$ & $24,1(29)$ \\
\hline $\begin{array}{l}\text { Дополнительный дистальный бугорок, с5 на } \mathrm{M}^{1} \\
\text { (выраженная форма) }\end{array}$ & $10(10)$ & $0(4)$ & $28,1(32)$ & $8,7(23)$ \\
\hline ** $\mathrm{M}_{1} 2$ med (II) & $22,2(9)$ & $0(1)$ & $4,5(22)$ & $0(15)$ \\
\hline $\mathrm{M}^{1} 1 \mathrm{pa}($ тип 3$)$ & $0(5)$ & $50(2)$ & $13,3(15)$ & $0(5)$ \\
\hline $\mathrm{M}_{1}$ tami & $0(15)$ & $0(5)$ & $0(44)$ & $14,3(21)$ \\
\hline М² Затек эмали (баллы 5-6) & $8,3(12)$ & $60(5)$ & $17,2(58)$ & $10,7(28)$ \\
\hline М2 Затек эмали (баллы 5-6) & $6,7(15)$ & $33,3(6)$ & $19,4(62)$ & $7,7(26)$ \\
\hline M 3 корня & $0(17)$ & $0(7)$ & $0(73)$ & $0(28)$ \\
\hline $\mathrm{P}^{1} 2$ корня & $50(16)$ & $12,5(8)$ & $34,2(73)$ & $37,9(29)$ \\
\hline Гиподонтия $\mathrm{M}^{3}$ (в среднем прав. + лев.) & $27,6(29)$ & $16,7(12)$ & $19,9(136)$ & $22,2(54)$ \\
\hline Гиподонтия $\mathrm{M}_{3}$ (в среднем прав. + лев.) & $11,1(27)$ & $25(12)$ & $21,5(135)$ & $33,3(51)$ \\
\hline Восточный комплекс (признаки с */4, в радианах) & $0,34 \mathrm{R}$ & $0,66 \mathrm{R}$ & $0,54 \mathrm{R}$ & $0,35 \mathrm{R}$ \\
\hline Западный комплекс (признаки с ** / 4, в радианах) & $1,17 \mathrm{R}$ & $0,80 \mathrm{R}$ & $1,29 \mathrm{R}$ & $0,94 \mathrm{R}$ \\
\hline
\end{tabular}

Следы биологических контактов с местным, более монголоидным, чем европейцы, населением присутствуют и в остальных группах. В Изюке, например, есть небольшой подъем частоты лопатообразных вторых резцов, шестибугорковых $\mathrm{M}_{1}$, затеков эмали, величины восточного комплекса. В то же время у трех северных групп отмечен высокий уровень грацильно- сти $\mathrm{M}_{1}$. В таксономическом отношении это показательная западная и южная особенность, часто присутствующая в сложных, мозаичных по антропологическому составу комплексах на севере Восточной Европы, в Поволжье, в Западной Сибири у татар и хантов, в Средней Азии. Обратим внимание еще на высокий суммарный уровень гиподонтии третьего моляра, мак- 
симальный (55\%) в группе XIX в. из Омска. Это яркий показатель незатухающего в эволюции редукционного процесса в зубной системе человека.

Бутырская серия имеет хорошо выраженную характеристику среднеевропейского одонтологического типа, весьма характерного для центральных европейских русских. И только высокий процент дистального гребня и бугорка tami допускает в ней либо смешение с азиатским населением, либо наличие в серии кровных родственников. При всех сопоставлениях эта группа занимает удаленное положение в европеоидном поле, что хорошо отражает график межгруппового анализа по методу главных компонент (рис. 2). Антагонистом ей и здесь является Тара, с промежуточной характеристикой по совокупности признаков, с наиболее высоким из всех восточных комплексов. Безусловно, это группа смешанного формирования. От нее все сравнительные группы (русские, метисные, тюркские) удалены на статистически достоверную величину среднего таксономического расстояния, СТР от 1,36 (чулымские тюрки и чулымско-русские метисы) до 2,04 радиан (Бутырское кладбище). В категории больших достоверно значимых величин Ананьино оказывается ближней к Таре русской группой своего региона.

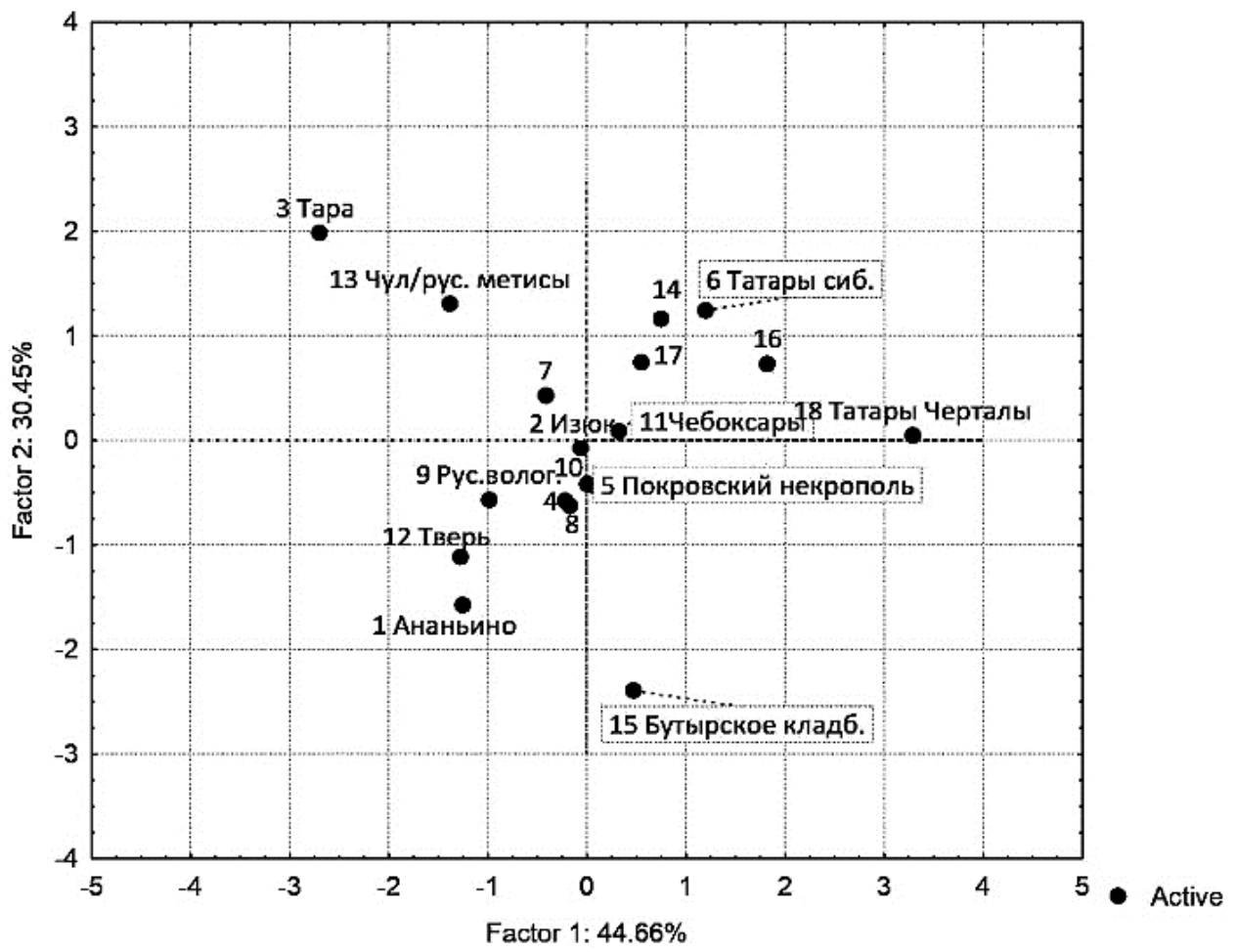

Рис. 2. Распределение русских и тюркских групп Западной Сибири и Восточной Европы в поле значений первых двух главных компонент (8 зубных маркеров, в радианах): 4 - Томск, 7 - русские Кеть, 8 - русские Чулым, 10 - Казань Кремль, 14 - чулымцы, 16-17 - татары тарские Токсай и Чеплярово

Четыре христианские (русские) группы Омского Прииртышья, в общем небольшого, соединенного судоходным речным бассейном участка Западной Сибири, удалены друг от друга на статистически достоверные биологические расстояния. Это может указывать на большую роль стохастических биосоциальных процессов в их формировании, относительную брачную изолированность друг от друга, пополнение численности за счет переселенцев из разных регионов, вероятно, с учетом родственных связей.

Ананьино сильно тяготеет к волжским группам, особенно верхнего Поволжья с финно-угорским дославянским субстратом (у нас это литературные данные по Твери). Очень низкий процент бугорка Карабелли, повышенный процент дистального гребня и варианта 1 pr (II) могут говорить о слабом местном влиянии либо особенностях самой группы. Изюк европеоидная группа с выраженным грацильным статусом зубной морфологии, как и в Ананьино. Это, возможно, вновь говорит о северо-западном векторе этно- генетических связей. Однако именно Изюк теснее связан с синхронными и современными русскими популяциями юго-восточного регионального направления (ТомскоНарымское Приобье, Енисей). А по величине восточного и западного одонтологических комплексов Изюк не различается с чулымско-русскими метисами. Из европейских групп к нему больше других приближаются выборки Среднего Поволжья - христианские захоронения в Чебоксарах и Казанском Кремле.

Изученные материалы Омского Прииртышья показали изменчивость локальных комплексов зубной морфологии в ранних популяциях русских сибиряков, сохранение в них европеоидной основы как доминанты одонтотипа. Можно предполагать высокий адаптивный биосоциальный потенциал ранних европейских переселенцев в Сибирь, которые формировали круги брачных связей открытого типа, в том числе для инородцев. Очевидно, что приоритетом оставалась этническая эндогамия, в основе которой тогда была конфессиональная общность. 


\section{ЛИТЕРАТУРА}

1. Харламова Н.В. Одонтологический материал XVI-XVIII вв. из христианских погребений Казанского Кремля // Вестник антропологии. М., 2007. Вып. 15, ч. II. С. $419-425$.

2. Харламова Н.В. Одонтология тверского населения XVI-XVIII веков // Вестник Московского университета. Сер. XXIII. Антропология. 2010. № 1. C. 91-94.

3. Геккер Н.Л. К характеристике физического типа якутов : (антропологический очерк). Иркутск : Типо-лит. П.Н. Макушина, 1896. 90 с. (Зап. Вост.-Сиб. отд. Рус. геогр. об-ва по этнографии. Т. III, вып. 1).

4. Майнов И.И. Помесь русских с якутами // Русский антропологический журнал. 1900. № 4. С. 37-57.

5. Майнов И.И. Русские крестьяне и оседлые инородцы Якутской обл. // Записки Русского географического общества. Отдел статистики. СПб., 1912. T. XII. 29 c.

6. Чугунов С.М. Антропологический состав населения города Томска по данным пяти старинных православных кладбищ : материалы для антропологии Сибири. Томск, 1905. Вып. 15. $197 \mathrm{c}$.

7. Дрёмов В.А. Население Томска в XVII-XVIII вв. // Очерки культурогенеза народов Западной Сибири. Томск : Изд-во Том. ун-та, 1998. T. 4: Расогенез коренного населения. С. 140-147.

8. Пежемский Д.В. Население Томска XVII-XIX вв. в системе антропологического разнообразия Европейской России // Вестник Томского государственного университета. История. 2017. № 49. С. 109-114.

9. Широбоков И.Г. Об антропологическом своеобразии населения Томска XVII-XVIII вв. // Сибирские исторические исследования. 2018 . № 4. C. $85-101$.

10. Багашёв А.Н., Антонов А.Л. К проблеме генезиса компонентов антропологической структуры русского старожильческого населения Омского Прииртышья // Культура русских в археологических исследованиях. Омск : Изд-во ОмГУ, 2005. С. $29-37$.

11. Багашёв А.Н., Антонов А.Л. Краниологическая характеристика русских старожилов Омского Прииртышья // Татаурова Л.В. Погребальный обряд русских Среднего Прииртышья XVII-XIX вв. по материалам комплекса Изюк-І. Омск : Апельсин, 2010. С. $247-280$.

12. Слепченко С.М., Татаурова Л.В. Палеопатологии у русских первопоселенцев Тарского Прииртышья (по материалам могильника Ананьино I) // Вестник археологии, антропологии и этнографии. 2012. № 3 (18). С. 92-101.

13. Рыкун М.П., Васильева Т.В. Результаты исследования антропологического материала с раскопок Богородицко-Алексиевского мужского монастыря г. Томска (конец XVIII-XIX вв.) // Вестник Томского государственного университета. История. 2013. № 3 (23). С. $199-201$.

14. Савенкова Т.М., Смушко С.Ю. К вопросу о составе населения Красноярского острога по краниометрическим данным // Междисциплинарные исследования в археологии, этнографии и истории Сибири. Красноярск : Сиб. фед. ун-т, 2017. С. 199-203.

15. Рейс Е.С., Савенкова Т.М. Демографическая характеристика населения города Красноярска XVII - начала XX вв. (по материалам православных некрополей) // Преодоление времени и пространства : статьи по актуальным проблемам охранно-спасательных работ на памятниках археологии Средней Сибири. Иркутск : Изд-во Ин-та географии СО РАН, 2019. С. 104-115.

16. Давыдова Г.М. Антропологические типы русских Сибири // Вопросы антропологии, диалектологии и этнографии русского народа. М., 1998. C. 28-36.

17. Лейбова Н.А., Пежемский Д.В. Население Албазинского острога по данным антропологических исследований // Албазинский острог: история, археология, антропология народов Приамурья. Новосибирск : Изд-во ИАЭТ СО РАН, 2019. С. 193-224.

18. Аксянова Г.А. Антропология старожильческих групп Сибирской Арктики // Культура русских в археологических исследованиях. Омск : Наука, 2017. С. 146-151.

19. Харламова Н.В., Лейбова (Суворова) Н.А., Бердников И.М., Бердникова Н.Е. Одонтологическая и остеологическая характеристики населения Иркутска XVIII - начала XIX вв. (по материалам некрополей) // Известия Иркутского государственного университета. Сер. Геоархеология. Этнология. Антропология. 2015. Т. 12. С. 110-131.

20. Ващаева В.Ф. Одонтологическая характеристика русских западных и северо-западных областей РСФСР // Вопросы антропологии. 1977. Вып. 56. С. 102-111.

21. Ващаева В.Ф. Одонтологическая характеристика русских центральных, южных и северных областей европейской части РСФСР // Вопросы антропологии, 1977. Вып. 57. С. 133-142.

22. Зубов А.А. Одонтология. Методика антропологических исследований. М. : Наука, 1968. 200 с.

23. Зубов А.А. Этническая одонтология. М. : Наука, 1973. 204 с.

24. Зубов А.А. Методическое пособие по антропологическому анализу одонтологических материалов. М. : ИЭА РАН, 2006.70 с.

25. Этническая одонтология СССР / отв. ред. А.А. Зубов, Н.И. Халдеева. М. : Наука, 1979. 256 с.

Galina A. Aksyanova, Institute of Ethnology and Anthropology RAS (Moscow, Russian Federation); Tomsk State University (Tomsk, Russian Federation). E-mail: gaksyanova@gmail.com

THE FIRST GENERATIONS OF THE 17-19th CENTURIES RUSSIAN POPULATION IN THE OMSK IRTYSH REGION ACCORDING TO DENTAL ANTHROPOLOGY

Keywords: Russians; Siberia; New time; physical anthropology; odontology.

The study aim is to describe the early permanent Russian populations of the central West Siberia from the permanent teeth morphology point of view, and to assess biological adaptation of these populations to their new living conditions. Dental morphology of 4 cranial samples of the early Russian settlers of the Middle Irtysh region was studied for the first time Ananyino I, Izyuk I, Tara 2013 and the Butyrskoe cemetery (Omsk). These samples were obtained during the archeological excavations by L.V. Tataurova, M.P. Chernaya and M.A. Korusenko ca in different areas of Omsk Oblast (Russia). All the samples are dated to the 17-19th cc. and represent rural and urban Orthodox populations.

These were compared with synchronous Russian samples from the Asian and European parts of the Russia, and with samples of Siberian Tatars. The comparison has shown the early Russian settlers of Siberia retained the European dental complex and were anthropologically different from neighboring groups of Islamic population. Most of the samples from the Omsk region display the following suit of features: absence of lingual displacement of the $\mathrm{I}^{2}$ (while cases of complete absence of this tooth are present); low frequencies of shoveling, deflecting wrinkle of the metaconid, lyre-like shape of the 1 pa fissure, enamel extensions at the second molars, and the accessory cusp c5 of the $\mathrm{M}^{1}$; high prevalence of the gracile type of the lower molars crown; absence of accessory third roots of the $\mathrm{M}_{1}$ accompanied by high frequencies of two-rooted $\mathrm{P}^{1}$. The Tara small sample more often deviates from the common dental complex of clearly pronounced Caucasoid traits. A substantial admixture from baptized non-Russian local population - likely the Tatars - can be hypothesized in this sample. Other samples also display limited biological contacts with native Asian populations, though less pronounced than at Tara. This is evident for example, in an increased frequency of the distal crest and deflecting wrinkle at Ananyino, 6th cusp of the $\mathrm{M}_{1}-$ at Izyuk, and a highly increased prevalence of the distal crest and tami cusp in the sample from the Butyrskoe cemetery. 
The Russian populations of the Omsk Irtysh region demonstrate a high level of local variation whereas the maximum differences are observed between the urban Omsk and Tara samples. A principal components analysis show that Ananyino is similar to populations from the northern part of Central Russia, Izyuk - to Russians from the Tomsk Ob region, Tomsk and Krasnoyarsk towns and Volga region, Tara - to the Turkic groups of lowland Siberia and metis Turkic-Russians, Butyrskoe cemetery - to the Russians from Tomsk and Kazan. The Tara sample demonstrates the closest similarity with Ananyino group.

The main conclusion of the present study is the populations carrying the Russian cultural traditions of the Modern Age were settling their new Trans-Ural habitats at the same time via biological adaptation to the environmental conditions of Western Siberia. But at the population level they retained the anthropological traits pointing to their European origin.

\section{REFERENCES}

1. Kharlamova, N.V. (2007) Odontologicheskiy material XVI-XVIII vv. iz khristianskikh pogrebeniy Kazanskogo Kremlya [Odontological material of the 16th -18 th centuries from the Christian burials of the Kazan Kremlin]. Vestnik antropologii-Herald of Anthropology. 15(2). pp. 419-425.

2. Kharlamova, N.V. (2010) Odontological materials from Tver XVI-XVIII centuries. Vestnik Moskovskogo universiteta. Ser. XXIII. Antropologiya Moscow University Anthropology Bulletin. 1. pp. 91-94. (In Russian).

3. Gekker, N.L. (1896) K kharakteristike fizicheskogo tipa yakutov: (antropologicheskiy ocherk) [On the physical type of the Yakuts. (Anthropological study)]. Zapiski Vostochno-Sibirskogo otdeleniya Russkogo geograficheskogo obshectva po etnografii. 3(1).

4. Maynov, I.I. (1900) Pomes' russkikh s yakutami [A cross between Russians and Yakuts]. Russkiy antropologicheskiy zhurnal. 4. pp. 37-55.

5. Maynov, I.I. (1912) Russkie krest'yane i osedlye inorodtsy Yakutskoy oblasti [Russian peasants and sedentary non-Russians of the Yakutsk region]. Zapiski Russkogo geograficheskogo obshchestva.12.

6. Chugunov, S.M. (1905) Antropologicheskiy sostav naseleniya goroda Tomska po dannym pyati starinnykh pravoslavnykh kladbishch : materialy dlya antropologii Sibiri [Anthropological Composition of the Tomsk Population According to the Data of Five Ancient Orthodox Cemeteries. Materials for Siberian Anthropology]. Vols. 15. Tomsk: [s.n.]

7. Dremov, V.A. (1998) Naselenie Tomska v XVII-XVIII vv. [The population of Tomsk in the 17th - 18th centuries]. In: Lukina, N.V., Kulemzin, V.M. \& Matyushchenko, V.I. Ocherki kul'turogeneza narodov Zapadnoy Sibir [Essays on the Culturogenesis of the Peoples of Western Siberia]. Vol. 4. Tomsk: Tomsk State University. pp. 140-147.

8. Pezhemsky, D.V. (2017) Population of Tomsk of the 17-th-19th Centuries and Anthropological Diversity of European Russia. Vestnik Tomskogo gosudarstvennogo universiteta. Istoriya - Tomsk State University Journal of History. 49. pp. 109-114. (In Russian). DOI: 10.17223/19988613/49/20

9. Shirobokov, I.G. (2018) On some distinctive anthropological characteristics of the population of Tomsk in the 17th to the 18th centuries. Sibirskie istoricheskie issledovaniya - Siberian Historical Research. 4. pp. 85-101. (In Russian).

10. Bagashev, A.N. \& Antonov, A.L. (2005) K probleme genezisa komponentov antropologicheskoy struktury russkogo starozhil'cheskogo naseleniya Omskogo Priirtysh'ya [On the genesis of components of the Russian old-timer population anthropological structure in Omsk Irtysh Region]. In: Tataurova, L.V. \& Borzunov, V.A. (eds) Kul'tura russkikh v arkheologicheskikh issledovaniyakh [Culture of Russians in Archaeological Research]. Omsk: Omsk State University. pp. 29-37.

11. Bagashev, A.N. \& Antonov, A.L. (2010) Kraniologicheskaya kharakteristika russkikh starozhilov Omskogo Priirtysh'ya [Craniological characteristics of Russian old-timers in Omsk Irtysh Region]. In: Tataurova, L.V. Pogrebal'nyy obryad russkikh Srednego Priirtysh'ya XVII-XIX vv. po materialam kompleksa Izyuk-I [The Funeral Rite of Russian Middle Irtysh Region in the 17-9th centuries on the Materials of the Izyuk-I Complex]. Omsk: Apel'sin. pp. 247-280.

12. Slepchenko, S.M. \& Tataurova, L.V. (2012) Paleopathology, bioarchaeological reconstructions, archaeology of the Russians, first settlers of West Siberia. Vestnik arkheologii, antropologii i etnografii. 3(18). pp. 92-101. (In Russian).

13. Rykun, M.P. \& Vasilyeva, T.V. (2013) The results of the study of anthropological material from the excavation of Bogoroditsko-Alekseevky friary of Tomsk (end of XVIII and XIX centuries). Vestnik Tomskogo gosudarstvennogo universiteta. Istoriya - Tomsk State University Journal of History. 3(23). pp. 199-201. (In Russian).

14. Savenkova, T.M. \& Smushko, S.U. (2017) K voprosu o sostave naseleniya Krasnoyarskogo ostroga po kraniometricheskim dannym [On the composition of the Krasnoyarsk prison population according to craniometric data]. In: Vdovin, A.S. \& Makarov, N.P. (eds) Mezhdistsiplinarnye issledovaniya $v$ arkheologii, etnografii $i$ istorii Sibiri [Interdisciplinary Research in Archeology, Ethnography and History of Siberia]. Krasnoyarsk: Siberian Federal University. pp. 199-203.

15. Reys, E.S. \& Savenkova, T.M. (2019) Demograficheskaya kharakteristika naseleniya goroda Krasnoyarska XVII - nachala XX vv. (po materialam pravoslavnykh nekropoley) [Demographic characteristics of the population of the city of Krasnoyarsk in the 17th - early 20 th centuries (based on materials from Orthodox necropolises)]. In: Preodolenie vremeni i prostranstva: stat'i po aktual'nym problemam okhranno-spasatel'nykh rabot na pamyatnikakh arkheologii Sredney Sibiri [Overcoming time and space. Articles on topical issues of security and rescue operations at archaeological sites in Central Siberia]. Irkutsk: SB RAS. pp. 104-115.

16. Davydova, G.M. (1998) Antropologicheskie tipy russkikh Sibiri [Anthropological types of Russians in Siberia]. In: Vlasova, I.V. (ed.) Voprosy antropologii, dialektologii $i$ etnografii russkogo naroda [Issues of anthropology, dialectology and ethnography of the Russian people]. Moscow: Institut. pp. 28-36.

17. Leybova, N.A. \& Pezhemsky, D.V. (2019) Naselenie Albazinskogo ostroga po dannym antropologicheskikh issledovaniy [The population of Fort Albazin according to anthropological research data]. In: Zabiyako, A.P. \& Cherkasov, A.N. (eds) Albazinskiy ostrog: istoriya, arkheologiya, antropologiya narodov Priamur'ya [Fort Albazin: History, Archeology, Anthropology of the Peoples of the Amur Region]. Novosibirsk: SB RAS. pp. $193-224$.

18. Aksyanova, G.A. (2017) Antropologiya starozhil'cheskikh grupp Sibirskoy Arktiki [Anthropology of old-timers' groups in the Siberian Arctic]. In: Tataurova, L.V. \& Borzunov, V.A. (eds) Kul'tura russkikh v arkheologicheskikh issledovaniyakh [Culture of Russians in Archaeological Research]. Omsk: Omsk State University. pp. 146-151.

19. Kharlamova, N.V., Leibova (Suvorova), N.A., Berdnikov, I.M. \& Berdnikova, N.E. (2015) Odontologic and Osteological Characteristics of the Irkutsk Population in the 18th - Early 19th Century (Based on the Necropolises Materials). Izvestiya Irkutskogo gosudarstvennogo universiteta. Ser. Geoarkheologiya. Etnologiya. Antropologiya - Bulletin of the Irkutsk State University. Geoarchaeology, Ethnology, and Anthropology Series. 12. pp. 110-131. (In Russian).

20. Vashchaeva, V.F. (1977a) Odontologicheskaya kharakteristika russkikh zapadnykh i severo-zapadnykh oblastey RSFSR [Odontological characteristics of the Russian western and northwestern regions of the Russian Socialist Federative Soviet Republic]. Voprosy antropologii. 56. pp. 102-111.

21. Vashchaeva, V.F. (1977b) Odontologicheskaya kharakteristika russkikh tsentral'nykh, yuzhnykh i severnykh oblastey evropeyskoy chasti RSFSR [Odontological characteristics of the Russian central, southern and northern regions of the European part RSFSR]. Voprosy antropologii. 57. pp. 133-142.

22. Zubov, A.A. (1968) Odontologiya. Metodika antropologicheskikh issledovaniy [Odontology. Methodology of Anthropological Research]. Moscow: Nauka.

23. Zubov, A.A. (1973) Etnicheskaya odontologiya [Ethnic odontology]. Moscow: Nauka.

24. Zubov, A.A. (2006) Metodicheskoe posobie po antropologicheskomu analizu odontologicheskikh materialov [Toolkit for anthropological analysis of odontological materials]. Moscow: RAS.

25. Zubov, A.A. \& Khaldeeva, N.I. (eds) (1979) Etnicheskaya odontologiya SSSR [Ethnic Odontology]. Moscow: Nauka. 